\title{
ESTRUTURA DA COMUNIDADE DOS DECAPODA (ANOMURA E BRACHYURA) EM COSTÕES ROCHOSOS PROTEGIDOS E EXPOSTOS DE ANCHIETA E GUARAPARI, ESPÍRITO SANTO, BRASIL
}

\author{
Braga, A.A. ${ }^{2,}{ }^{,}$; Ribeiro, C.C. ${ }^{1}$; Nunes, E.T. ${ }^{2}$ \& Bertini, G. ${ }^{1}$ \\ ${ }^{1}$ Universidade Estadual Paulista (UNESP), Laboratório de Biologia e Cultivo de Crustáceos (LABCRUST). \\ 2 Universidade Federal do Espírito Santo (UFES). \\ *Autor correspondente: dricrab@yahoo.com.br
}

\begin{abstract}
Os costões rochosos são ecossistemas susceptíveis a muitos impactos antrópicos, sendo assim, a ausência de informações sobre sua biota dificulta sua caracterização e, consequentemente, a realização de medidas de conservação e restauração. Dentro deste contexto, este estudo teve como objetivo analisar a comunidade de anomuros e braquiúros nos costões protegidos e expostos de Anchieta e Guarapari, litoral do Espírito Santo, enfocando os índices ecológicos (abundância, riqueza, diversidade, equitabilidade e dominância). Além disso, foi estudada a variação da comunidade em relação aos períodos chuvoso e seco. As coletas foram realizadas bimestralmente, de outubro de 2014 a setembro de 2015, totalizando três amostragens em cada período. Os animais foram coletados manualmente, com esforço de captura de um coletor por 10 minutos na região intertidal dos costões rochosos de cada região (Anchieta e Guarapari). Adicionalmente, a temperatura da água e a salinidade foram mensuradas, e a pluviosidade obtida em estação meteorológica. Os índices ecológicos (abundância, riqueza, diversidade, equitabilidade e dominância) foram comparados pela ANOVA three way fatorial. A influência dos fatores ambientais na abundância das espécies foi verificada pela análise de correlação canônica. Foram obtidos 3.156 indivíduos representados por 14 espécies. Os ermitões Clibanarius antillensis Stimpson, 1859 e Calcinus tibicen (Herbst, 1791) e o braquiúro Eurypanopeus abbreviatus (Stimpson, 1860) foram as espécies mais abundantes. O número de indivíduos foi estatisticamente maior em Guarapari (ANOVA; $p<0,05$ ) estando relacionado a alta frequência dos ermitões $C$. antillensis e $C$. tibicen. A riqueza de espécies e a diversidade foram maiores nos costões protegidos de ambas as regiões $(p<0,05)$, provavelmente por estes serem compostos por rochas de variados tamanhos e sedimentos heterogêneos, proporcionando maior disponibilidade de micro habitats. Os fatores ambientais amostrados não apresentaram correlação com a abundância das espécies, em função da pequena variação desses nos períodos chuvoso e seco. Dessa forma, as comunidades de Anomura e Brachyura, possivelmente, são mais influenciadas por interações biológicas (competição, predação, etc.) e as características fisiográficas dos costões (inclinação, rugosidade, etc.) do que pelos fatores ambientais analisados.
\end{abstract}

Palavras chave: região intertidal, índices ecológicos, crustáceos, sul capixaba. 